\title{
Effect of Melatonin on Ovarian Function by Over-expression and Down -Regulation of Genes Related to Steroidogenesis in Pinealectomized Rats
}

\author{
Maganhin $\mathrm{CC}^{1}$, Simões $\mathrm{RS}^{2}$, Girão JHRC ${ }^{3}$, Fuchs $\mathrm{LFP}^{2}$, Sasso GRS ${ }^{3}$, Carbonel AAF ${ }^{3}$, Reis $\mathrm{LA}^{5}$, Simões \\ $\mathrm{MJ}^{3}$, Baracat EC ${ }^{2}$, Soares Jr JM ${ }^{2}$ \\ ${ }^{1}$ Gynecology Department, Federal University of São Paulo, Paulista School of Medicine UNIFESP, Sao \\ Paulo, Brazil \\ ${ }^{2}$ Department of Obstetrics and Gynecology, University of São Paulo, USP-Brazil \\ ${ }^{3}$ Department of Morphology and Genetic, Federal University of São Paulo, Paulista School of Medicine \\ UNIFESP, Sao Paulo, Brazil \\ ${ }^{4 .}$ Department of Molecular Biology, Federal University of São Paulo, Paulista School of Medicine \\ UNIFESP, Sao Paulo, Brazil \\ ${ }^{5}$ Department of Nephrology, Federal University of São Paulo, Paulista School of \\ Medicine UNIFESP, Sao Paulo, Brazil
}

Objective: To analyze the expression of genes related to steroidogenesis in ovary of pinealectomized rats. Methods: 32 adult female virgin rats, with regular estrous cycle, were pinealectomized (PNE) and equally divided into two groups, as follows: GI - control group (PNE that received vehicle solution) and GII (PNE treated with melatonin, 10 $\mu \mathrm{g} / \mathrm{night}$, per animal), during 60 consecutive days. After treatment, the animals were euthanized by overdose of ketamine and xilazine, some ovaries were collected, kept in liquid nitrogen and stored at $-80^{\circ} \mathrm{C}$ for posterior expression analyses by cDNA microarray (Kit GeneChip ${ }^{\circledR}$ Rat Genome 2302.0 Array, Affymetrix) of genes related to ovarian functions. The microarray assay was carried out in triplicate for each group. Data were normalized and subjected to the GeneChip ${ }^{\circledR}$ Operating Software and later confirmed by the DNA-Chip Analyzer (dChip) software of secundar analyses. Gene expressions were considered significantly different when they were $1.5 \mathrm{x}$ over or low expressed, when compared to the control group. Some samples were appropriately kept for posterior RT-PCR analyses and others were processed for paraffin embedding.

Results: The GII showed one hundred one overexpressed genes and seventy-two low expressed genes compared to GI. The genes related to ovarian steroidogenesis were statistically significant overexpressed (Inibin beta-A, Folistatin and Abl-Interactor1) and low expressed (Prostaglandin D2 synthase, LIM Homeobox 9 and Glutathione S-transferase Mu 1), in the GII. Among the overexpressed genes, the Inibin beta-A showed the higher expression. Based on these data, we later confirmed the overexpression of Inibin beta-A by RT-PCR (GII > GI, p<0.01) and by immunohistochemistry, which showed higher immunoreactivity in GII (74.43 \pm 2.89$)$ in the follicular and interstitial cells, as well as in the inner teca cells, compared to GI $(54.32 \pm 4.32)$.

Conclusion: Our data show that melatonin may influence ovarian function by the overexpression and down-regulation of steroidogenesis related genes in ovary of PNE rats.

\section{References:}

Maganhin CC, Fuchs LF, Simões RS, Oliveira-Filho RM, de Jesus Simões M, Baracat EC, Soares JM Jr. Effects of melatonin on ovarian follicles. Eur J Obstet Gynecol Reprod Biol. 2013;166(2):178-84.

Financial support by FAPESP - 2006/60412-7; 2007/54398-4; 2011/51581-8 


\section{Microarray e RT-PCR}

\begin{tabular}{|c|c|c|}
\hline Up-regulated genes & Symbols & $\mathrm{R}$ \\
\hline Inhibin Beta-A & INHBA & $\uparrow 2,400$ \\
\hline Follistatin & FST & $\uparrow 2,030$ \\
\hline Abl interactor 1 & ABII & $\uparrow 2,010$ \\
\hline Ectoderm-neural cortex protein 1 & ENCl & $\uparrow 1,990$ \\
\hline T-box transcription factor 18 & TBx18 & $\uparrow 1,890$ \\
\hline Glutamine-rich protein 1 & QRICHI & $\uparrow 1,860$ \\
\hline $\begin{array}{l}\text { Gremlin-2 homolog, cysteine knot superfamily, (Rattus } \\
\text { norvegicus) }\end{array}$ & GREMR & $\uparrow 1,760$ \\
\hline Hepatitis $A$ virus cellular receptor 1 homolog & Haver1 & $\uparrow 1,730$ \\
\hline Small nuclear ribonucleoprotein D1 polypeptide & Snrpdl & $\uparrow 1,20$ \\
\hline Centromere-associated protein E & Cenpe & $\uparrow 1.710$ \\
\hline \multicolumn{3}{|l|}{$A^{R=R a t i o ~ b e t w e e n ~ G I I ~ a n d ~ G I ~}$} \\
\hline Down-regulated genes & Symbols & $\mathbf{R}$ \\
\hline Prostaglandin D2 synthase (brain) & Ptgds & $\downarrow 3.062$ \\
\hline LIM homeobox protein Lhxo & $\operatorname{Lhx} 9$ & $\downarrow 2.857$ \\
\hline Glutathione S-transferase Mu 3 (Mus musculus) & Gstm3 & $\downarrow 2.132$ \\
\hline Rab40b, member RAS oncogene family & Rab40b & $\downarrow 1.863$ \\
\hline Solute carrier family 34 (Sodium phosphate), member 2 & sic 3432 & $\downarrow 1.815$ \\
\hline Major histocompatibility complex, class II, Alpha DM & $\begin{array}{l}\text { HLA. } \\
\text { DMA }\end{array}$ & $\$ 1.757$ \\
\hline Aldehyde dehydrogenase family 1 , member $A 3$ & Aldhla3 & $\$ 1.744$ \\
\hline Major histocompatibility complex, class II, Beta DM & $\begin{array}{l}\text { HLA- } \\
\text { D.MB }\end{array}$ & $\$ 1.739$ \\
\hline Chemokine (C.X-C motif) ligand 10 & Cxel10 & $\downarrow 1.735$ \\
\hline Basic helix-loop-helix family, member et1 & Bhlhet1 & $\$ 1.728$ \\
\hline
\end{tabular}

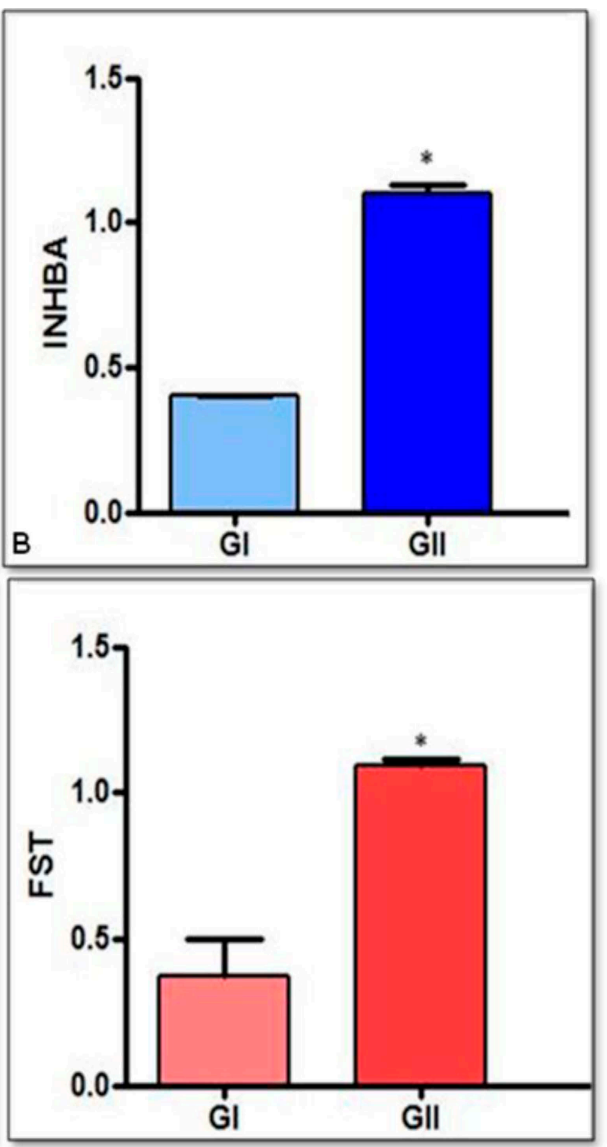

Fig. 1A - List of up-regulated and down-regulated genes in GII in relation to GI. B - Mean and standard deviation of $2-\Delta \Delta \mathrm{Ct}$ from the RT- PCR of the INHBA gene between GII and GI, using the same samples used in microarray experiments ilNHBA- $p=0.007)$. $C$ - Mean and standard deviation of $2^{-\Delta \Delta \mathrm{Ct}}$ from the RT- PCR of the FST gene in GII and GI, using the same microarray samples (FST-p=0.04).

\section{Immunohistochemical- Inhibin}
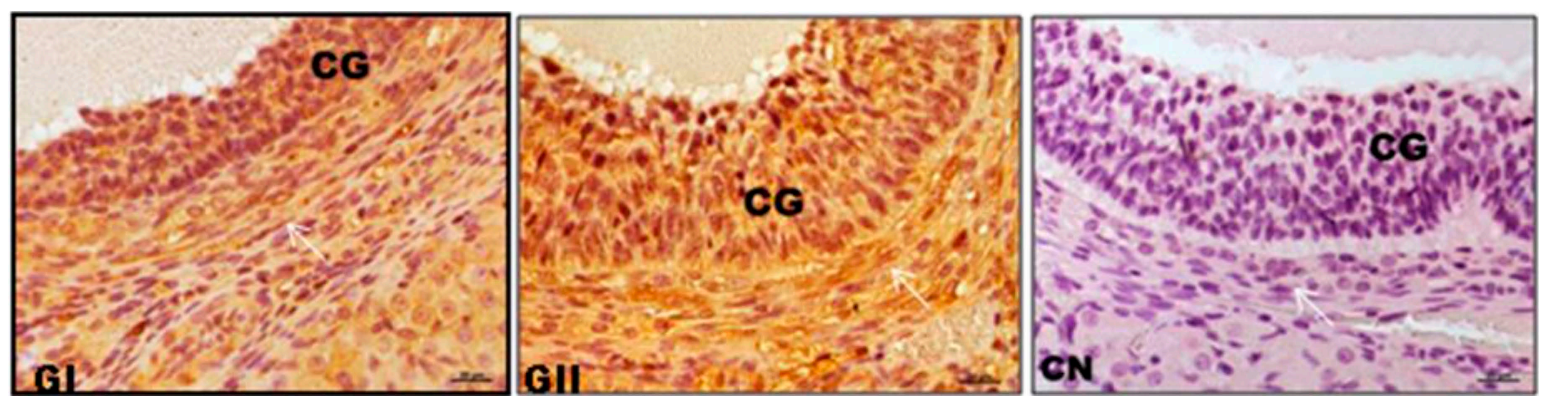

Fig. 2 - Photomicrographs of sections of ovaries belonging to groups (GI and GII). Observe the expression of inhibin was higher in GII (pinealectomized treated with melatonin) $(\mathrm{GII}=74.43 \pm 2.89 *$ ) in granulosa cells (GC) and theca interna (arrow) compared with GI (pinealectomized treated with vehicle) . (GI $=54.32 \pm 4.32 *)(* \mathrm{p}<0.05) .400 x$ Increase Counter-Staining: Hematoxylin; negative control $(\mathrm{CN})$. 